\title{
Efektifitas Sertifikasi Tanah Wakaf di Indonesia: Analisis Komparatif Fikih dan Hukum Positif
}

\author{
Pranadiana Marginingrum \\ Universitas Islam Negeri Sunan Ampel Surabaya, Indonesia \\ pranadianasiamanxa@gmail.com \\ Affan Riadi \\ Institut Ilmu Keislaman Annuqayah Sumenep. Indoenesia \\ affanriadi8@gmail.com
}

\begin{abstract}
Abstrack:
This research is a literature study that is supported by the evidence of field research on the status of uncertified waqf land. The consensus on the legal status of the waqf land according to both fiqh and adat in the community is still being contested. Some say that the donated land does not need to be certified because it deals with issues of worshiping God, while others say that the donated land must be certified. This phenomenon has brought society into a dilemma, eventually leading to stagnation. Therefore, this study seeks to answer two questions, namely; 1) what is the legal status of the waqf land that does not have a certificate? 2) How is the legal protection for the waqf land that does not have a certificate? This research is a normative juridical research which aims to study the principles and principles that exist in the science of law. The information used consists of primary, secondary and tertiary legal materials. The results of this research are to show that the status of waqf land that does not have a certificate is legal in Islamic law and the person who donates will also get reward as long as it fulfills the principles and provisions set out in sharia. On the other hand, in the statutory law, the status of waqf land which does not have a certificate does not have the power in the waqf land law that Nazhir recommends to certify the donated land.
\end{abstract}

Keywords: waqf land; certificate; legal effectiveness 


\section{Latar Belakang}

Wakaf ini serta dapat dipahami sebagai suatu upaya menahan dari sesuatu benda pokok dan memberikan manfaatnya di jalan Allah SWT. Wakaf akan sanggup disalurkan dengan bermacam bentuk yang bertujuan agar kebaikan kita sesuai dengan ketentuan syariat Islam, misal membangun masjid, sekolah, sumur, panti jompo, maupun mengolah tanah maupun sawah, yang dimana faedahnya sanggup diberikan kepada saudara, fakir miskin, anak generasi, serta kepentingan publik yang yang ada. Tidak cuma itu, walaupun seseorang wakif sudah wafat dunia, wakaf yang telah diberikan pada semasa hidupnya senantiasa mendapatkan pahala yang mengalir nonstop. Oleh karna itu, pengelola wakaf (nazhir) ini butuh memakai dari hasil harta barang yang sudah diwakafkan secara berkepanjangan demi mendapatkan faedah secara bebas serta bisa bernilai ibadah. ${ }^{1}$

Tugas sosial dari wakaf ialah peninggalan yang berharga dalam proses pembangunannya. Tentang ini dikarenakan wakaf selaku salah satu upaya penyusunan dari sifat serta karakter dari seseorang muslim yang bertujuan buat membebaskan sebagian hartanya demi kepentingan orang lain, serta membangun investasi yang bernilai sangat mulia, karna orang yang mewakafkannya tidak bakal memperhitungkan waktu serta menemukan keuntungan dari modul tersebut. Peran wakaf ini serta terhitung peranan ekonomi umat ini sangat tampak jelas, karna dengan terdapatnya modal maupun lahan yang dikelolanya dengan secara produktif bakal menopang penduduk dalam penuhi kebutuhan hidup orang miskin dengan memotivasi dalam etos kerja. ${ }^{2}$

Permasalahan tentang wakaf yang terselip di Indonesia ini terlebih lagi sudah diatur dalam hukum positif, yakni antara lain UndangUndang( UU) No 41 Tahun 2004 Tentang Wakaf, Peraturan Pemerintah( PP) No 42 Tahun 2006 Tentang Penerapan UU No 41 Tahun 2004 tentang Wakaf, PP No 28 Tahun 1977 Tentang Wakaf Tanah Kepunyaan, serta UU No 5 Tahun 1960 Tentang Peraturan Dasar Pokok Agraria. Oleh karna itu, masalah- masalah tanah wakaf ini sangat erat kaitannya dengan perkara sosial serta adat istiadat, sehingga dalam peraturan penerapan wakaf ini dilaksanakan cocok dengan permasalahan sosial serta adat istiadat yang terdapat. Hingga ketentuan penerapan wakaf ini dilaksanakan cocok dengan hukum adat yang berlaku dalam masayarakat dengan tidak kurangi isi nilai- nilai Islam yang telah terselip didalam hukum wakaf itu sendiri.

\footnotetext{
${ }^{1}$ Sri Nurhayati, Akuntansi dan Manajemen Wakaf. (Jakarta: Penerbit Salemba Empat, 2019), 12.

2 Dimas Fahmi Fikri; Afif Noor, "Reformasi Hukum Wakaf di Indonesia Studi terhadap Wakaf Atas Kekayaan Intelektual”, Jurnal Al Ahkam, 22, 1 (2012): 44.
} 
Undang- Undang No 41 Tahun 2004 tentang Wakaf ini paling tidak sudah berjalan tujuh belas tahun. Oleh karna itu, kasus sertifikasi tanah wakaf ini masih didapati perkara yang rada pelik, banyak teradinya permasalahan yang terikat dengan perkara sertifikat tanah semacam, informasi tanah yang masih belum lengkap, wakif telah wafat, nazhir telah wafat, sehingga sertifikat tanah wakaf ini tidak sanggup dituntaskan secara efisien serta efektif disebabkan faktor- faktor tertentu.

Registrasi tanah wakaf ini serta bisa dicoba buat mendapatkan proteksi serta kepastian dari hukum biar sanggup memudahkan dalam proses pembuktian buat seorang yang bakal mewakafkan sebagian hartanya. ${ }^{3}$ Dengan diperlukannya registrasi serta pencatatan tanah wakafe, Badan Pertanahan Nasional( BPN) ini punya tujuan ialah buat membagikan kepastian hukumnya serta proteksi hukum kepada Negeri terhadap tanah yang sudah diwakafkan kepada pewakaf serta telah ada status hukum wakaf yang sangat jelas serta cocok dengan hukum positif yang berlaku di Indonesia. ${ }^{4}$

Masih banyak lagi kasus tanah wakaf yang masih belum bersertifikat, dalam mempraktekkan perwakafan yang dicoba sepanjang ini rata- rata masih banyak peristiwa yang tulus serupa pada disaat pengikraran wakif yang terselip dihadapan para nazhir serta para saksi tanpa terdapatnya data yang secara tertulis maupun data yang kurang konkret. Praktek perwakafan ini serta masih terselip yang kurang memperdulikan dengan terdapatnya hukum positif, bagi pelaksana wakaf ini yang terutama dalam perwakafan merupakan legal dalam pengikraran wakaf bagi hukum Islam. Sehingga bisa ditinjau dari sudut hukum perundangan dalam peran tanah wakaf ini jadi tidak jelas serta bisa jadi besar bakal berlangsung persengketaan tanah wakaf di sesudah itu hari dan juga bisa berdampak terancamnya keberadaan serta hilangnya peranan dari keuntungan tanah wakaf tersebut. ${ }^{5}$

Ada pula yang sebagai fokus permasalahan dalam studi ini yakni bagaimanakah status hukum tanah wakaf tanpa sertifikat? Gimana tanah wakaf tanpa sertifikat menemukan proteksi status hukum tanah wakaf tanpa sertifikat.

\footnotetext{
${ }^{3}$ Zahrul Fatahillah, "Perlindungan Hukum Tanah Wakaf Yang Tidak Memiliki Sertifikat (Studi terhadap Putusan Wakaf di Mahkamah Syar'iyah Aceh)”, Jurnal Kalam, 7,1 (2019), 66.

${ }^{4}$ Ibid., 68.

${ }^{5}$ Ibid., 69.
} 


\section{Kajian Teori \\ Konsep Wakaf}

Kata wakaf berasal dari bahasa Arab, ialah dari sumber waqafa yang maksudnya diam di tempat, menahan, berdiri maupun menyudahi. Dalam artian dari kata menahan yang diartikan merupakan menahan harta yang dipunyai buat diwakafkan serta tidak dipindah dari kepemilikannya. ${ }^{6}$ Sebaliknya buat arti sebutan dari wakaf bagi ulama membagikan artian yang cocok dengan mazhab yang mereka simak sehingga banyak timbulnya artian wakaf apabila di wujud dalam sebutan yang barangkali sedikit berbeda. Namun di Indonesia ini telah terdapat penafsiran wakaf yang tertulis di dalam Undang- Undang wakaf yang dimana wakaf mempunyai arti ialah sesuatu perbuatan hukum wakif buat memisahkan maupun menyerahkan dari sebagian harta barang yang dimilikinya yang bertujuan buat dimanfaatkan selamanya ataupun buat jangka waktu panjang cocok dengan kepentingannya dimana dalam pemanfaatan wakaf tersebut buat keperluan ibadah ataupun kesejahteraan universal yang lain yang terdapat di penduduk menurut syariah. $^{7}$

\section{Efektivitas Hukum}

Kata efektifitas berasal dari kata efektif, yang bermakna terbentuknya dampak ataupun sesuatu perbuatan terbentuknya akibat yang bakal dikehendaki. ${ }^{8}$ Sebaliknya efektivitas ialah kondisi dimana ia hendak diperankan buat memantau. Pada dasarnya efektivitas merupakan sesuatu jenjang keberhasilannya dalam meraih sesuatu tujuan yang kita impikan. Efektivitas ialah pengukuran dimana bakal tercapainya dalam sesuatu target ataupun sesuatu tujuan yang diidentifikasikan tadinya. Apabila yang hendak dibahas ini tentang efektivitas perundang- undangan, sehingga bisa dikatakan efektifitas undang- undang ini. Terdapat sebagian sebab yang bergantung, antara lain: ${ }^{9}$

a. Pengetahuan tentang substansi (isi) dari perundang-undangan tersebut.

\footnotetext{
${ }^{6}$ Sri Nurhayati; Suryani, Akuntansi dan Manajemen Wakaf. (Jakarta: Penerbit Salemba Empat, 2019) 13-14.

${ }^{7}$ Tri Bakti In Hidayatulloh, "Efektivitas Undang-Undang Nomor 41 Tahun 2004 Pasal 68 Tentang Adminstratif Keterlambatan Pendaftaran Tanah Wakaf Oleh Pejabat Pembuat Akta Ikrar Wakaf (Studi di Kecamatan Sukodadi Kabupaten Lamongan)", Skripsi UIN Maulana Malik Ibrahim Malang (2017), 19.

${ }^{8}$ Itaq Puspadewi, "Pengaruh Komunikasi Terhadap Efektifitas Kerja Pada Badan Perencanaan Pembangunan Daerah Kabupaten Kutai Barat”, Jurnal Ilmu-Ilmu Sosial, 3, 1 (2014), 5.

9 Achmad Ali. Menguak Teori Hukum (Legal Theory) dan Teori Peradilan (Judicialprudence) Termasuk Interprtasi Undang-Undang (Legisprudence). (Jakarta: Penerbit Kencana, 2009), 378.
} 
b. Cara-cara buat mendapatkan pengetahuan tersebut.

c. Institusi yang terikat terdapatnya dari ruang lingkup perundangundangan didalam penduduk.

d. Gimana proses lahirnya sesuatu perundang- undangan, yang tidak boleh dilahirkan secara tergesa- gesa buat kepentingan praktis( sesaat), yang diistilahkan oleh Gunnar Myrdall selaku sweep legislation ( undang- undang sapu), yang ada mutu yang kurang baik serta tidak cocok dengan apa kebutuhan penduduk.

Oleh karna itu, Achmad Ali berkomentar jika banyak sebab yang pengaruhi efektifitas perundang- undangan, ialah aparat penegak hukum yang mempunyai profesionalisme serta optimalitas dalam melaksanakan kedudukan yang sangat berguna, kewenangan serta peranan penegak hukum. Di dalam pemahaman tugas yang dibebankan kepada diri mereka ataupun dalam penegakan perundang- undangan tersebut. ${ }^{10}$

Sebaliknya Soerjono Soekanto ini berkomentar jika terdapat 5 perihal di dalam tolak ukur daya guna penegakan hukum yaitu: ${ }^{11}$

1. Aspek Hukum

Hukum berperan bagaikan kedudukan buat keadilan, kepastian serta kemanfaatan. Dalam praktiknya watak tersebut sangat khusus serta nyata, sebaliknya watak keadilan ini sangat abstrak sehingga pada saat hakim memutuskan sesuatu perkaranya dalam pelaksanaan Undang- Undang terkadang nilai keadilan itu tidak bisa terwujud. Oleh sebab itu bila memandang perkara yang berkaitan dengan hukum, sehingga paling tidak keberadaan dalam berkeadilan hendak menjadikan bagaikan prioritas utama sebab dalam Undang- Undang ini perihal tersebut tidak cuma dari perspektif hukum perundangundangan saja.

2. Aspek Penegakan Hukum

Dalam berfungsinya hukum, mentalitas ataupun karakter petugas penegak hukum ini memainkan peranan yang sangat berarti. Apabila peraturan tersebut telah baik, tapi jika mutu petugas hukum itu kurang baik, sehingga terdapat kemungkinan terdapat perkara yang dialami. Terdapatnya kecenderungan yang sangat kokoh di golongan warga buat memaknai hukum bagaikan petugas ataupun penegak hukum, maksudnya hukum ini diibaratkan dengan terdapatnya tingkah laku yang nyata dalam petugas ataupun penegak hukum. Bila mereka

\footnotetext{
${ }^{10}$ Ibid, 379.

11 Soerjono Soekanto, Faktor-Faktor yang Mempengaruhi Penagakan Hukum. (Jakarta: Raja Grafindo Persada, 2007), 5.
} 
melaksanakan kekuasaannya, lazimnya perkara bakal timbul sebab perilaku ataupun perlakuan yang diduga di luar kekuasaannya ataupun sikap lain yang disangka menghancurkan citra serta kekuasaan aparat penegak hukum.

3. Aspek Fasilitas ataupun Sarana Pendukung

Aspek fasilitas ataupun sarana pendukung ini sangat mencakup dari fitur lunak serta fitur keras. Bagi Soerjono Soekanto kalau seandainya para penegak hukum ini tidak mencukupi kendaraan serta alat- alat komunikasi yang seimbang, sehingga para penegak hukum ini tidak sanggup bekerja dengan baik. Oleh karna itu, fasilitas ataupun sarana juga punya peranan yang sangat berguna di dalam penegakan hukum. Tanpa sarana yang disediakan, tidak bakal terdapat koordinasi aparat penegak hukum yang semestinya sebagai kedudukan yang sesungguhnya.

4. Aspek Masyarakat

Penegak hukum asal usulnya dari warga yang bertujuan buat meraih kedamaian di kawasan warga. Tiap masyarakat warga ataupun kelompok sedikit ataupun banyaknya hingga hendak memiliki pemahaman hukum itu. Perkara yang muncul yakni taraf kepatuhan hukum, ialah terhitung kepatuhan hukum yang besar, lagi, ataupun kurang. Terdapatnya ketaatan hukum pada warga terhadap hukum tersebut, hingga terdapat salah satu penunjuk yang berperan hukum tersebut bersangkutan.

5. Aspek Kebudayaan

Kebudayaan pada dasarnya mencakup nilai- nilai dasar hukum yang berlaku, ialah konsep- konsep abstrak tentang apa yang anggap mereka baik karenanya (sehingga penyelenggaraan hukum yang terdapat di lapangan bakal berlangsung pertentangan antara kepastian hukum serta keadilan. Kepastian Hukum dituruti) serta apa yang disangka kurang baik (sehinga dihindari). Sehingga, kebudayaan Indonesia ialah dasar pelaksanaan hukum adat yang berlaku. Disamping itu berlaku pula buat hukum tertulis (perundang- undangan), yang dibangun oleh kalangan tertentu dalam warga dimana mereka memiliki kekuasaan serta wewenang buat itu. Hukum perundang- undangan itu mesti bisa mencerminkan nilai- nilai yang jadi dasar dari hukum adat tersebut, sehingga hukum dalam perundang- undangan tersebut bisa berlaku secara aktif. ${ }^{12}$

12 Iffa Rohmah. 2016. Penegakkan Hukum. http://pustakakaryaifa.blogspot.com. Diakses : Pukul 16.40 WIB, Tanggal 18 Januari 2021. 
Kelima aspek yang diuraikan diatas terdapat silih keterkaitan dengan eratnya, sebab jadi sesuatu perihal pokok dalam menegakan hukum yang terdapat, dan bagaikan tolak ukur dari efektifitas penegakan hukum. Dari 5 aspek dalam penegakan hukum itu sendiri merupakan titik sentralnya. Perihal ini diakibatkan sebab kalau undang- undangnya ini disusun oleh penegak hukum, serta pelaksanaannya juga dilaksanakan oleh penegak hukum serta penegakan hukumnya pula dimana seorang ini yang hendak jadi panutan untuk warga luas. ${ }^{13}$

\section{UU Nomor 41 Tahun 2004 Tentang Wakaf}

Dengan hadirnya Undang-Undang Republik Indonesia Nomor. 41 tahun 2004 tentang Wakaf, merupakan Undang- Undang yang sangat dinantikan oleh bangsa Indonesia paling utama untuk yang memeluk agama Islam. Karna pada permasalahan perwakafan ini sudah jadi problem yang bisa jadi lumayan lama serta belum terdapatnya UndangUndang yang bisa jadi secara eksklusif tentang wakaf, sehingga perwakafan di Indonesia kurang tumbuh secara maksimal. Gagasan serta pemikiran tersebut sudah menghasilkan peraturan tentang wakaf, penerapan wakaf, yang hendak dilaksanakan oleh warga umat Islam di Indonesia yang masih memakai kerutinan keagamaan serupa menerapkan suatu perbuatan hukum perwakafan tanah baik itu dengan metode lisan yang mensugesti kepada seorang ataupun lembaga tertentu atas dasar keyakinan, kerutinan memandang kalau wakaf ini bagaikan amal shaleh yang bisa jadi memiliki nilai- nilai yang tidak butuh lewat prosedur administratif buat memuliakan kepada Tuhan, serta buat dikira bagaikan peninggalan milik Allah siapapun tidak bakal berani campur tangan tanpa izin Allah. ${ }^{14}$

Aplikasi penerapan wakaf tersebut pada kesimpulannya hendak jadi setengah ekspedisi, serta perkara ini wajib dinaikan buat mengangkut perkara yang terikat keabsahan hukum peninggalan wakaf yang bisa memunculkan perselisihan akibat kegagalannya. Terdapat bukti-bukti yang kongkret menampilkan jika benda-benda bersangkutan tersebut sudah diwakafkan.

Berlandaskan Undang-Undang Republik Indonesia No 41 Tahun 2004 tentang Wakaf yang diundangkan pada 27 Oktober 2004, pemerintah negara menyatakan apresiasi atas Filantropi Islam serta penuh harapan buat itu wakaf ini bisa tumbuh dengan dinamika serta transformasi yang

\footnotetext{
${ }^{13}$ Ibid, 53.

14 Ahmad Djunaidi; Thobib Al Asyhar, Menuju Era Wakaf Produktif. (Jakarta; Mumtaz Publishing, 2005), 57.
} 
terdapat dalam warga, dan sesuatu momentum yang bisa jadi sangat ini strategis dalam mengupayakan dalam pemberdayaaan wakaf.

Oleh sebab itu, dalam Undang-Undang No 41 Tahun 2004 tentang Wakaf, pemerintah pula sangat mencermati penyusunan administrasi wakaf yang membagikan kepastian hukum untuk wakif (pewakaf), nazhir (pengelola) serta mauquf 'alaih (obyek wakaf) serta menekan pemakaian peninggalan wakaf yang bisa jadi sudah tidak produktif lagi hendak terus menjadi efisien.

Tidak hanya itu, Jaih Mubarok dalam bukunya" Wakaf Produktif" mengklarifikasi alasan ataupun sebab dibentuknya Undang- Undang No 41 Tahun 2004 tentang Wakaf sebagai berikut: ${ }^{15}$

1. Memajukan kesejahteraan universal. Buat meraih tujuan tersebut sehingga butuh dibesarkan serta digali kemampuan yang ada pada lembaga keagamaan serta mempunyai guna ekonomi. Diantara langkah yang di nilai strategis, bisa tingkatkan kesejahteraan universal ialah dengan tingkatkan kedudukan wakaf bagaikan lembaga keagamaan yang semula cuma digunakan sebagai fasilitas ibadah serta aktivitas sosial, jadi pranata yang mempunyai kekuatan ekonomi yang hendak diyakini bisa memajukan kesejahteraan universal yang lain. Oleh sebab itu, kemampuan gerakan keagamaan Islam pula butuh digali serta dibesarkan penggunaannya sesuai dengan kaidah ajaran Islam.

2. Aplikasi wakaf yang terdapat di masa saat ini belum seluruhnya bisa berjalan dengan tertib serta efektif. Salah satu buktinya dalam harta wakaf, harta tidak dapat dipelihara dengan baik, diabaikan, apalagi terdapat yang jadi tangan pihak ketiga sebab melanggar hukum. Keterlantaran serta pengalihan barang wakaf ini ke tangan pihak ketiga terjalin sebab: (1) ada kelalaian ataupun ketidakmampuan dari pihak nazhir dalam mengelola serta meningkatkan peninggalan wakaf tersebut; (2) perilaku warga yang bisa jadi kurang hirau ataupun belum menguasai status harta barang wakaf yang sepatutnya dilindungi bagaikan media buat menggapai kesejahteraan universal yang cocok dengan tujuan, fungsi, serta peruntukan wakaf.

Sebagaimana uraian dari 2 sebab tersebut, para penyusun UndangUndang No 41 Tahun 2004 tentang Wakaf meyakinkan kalau pembuatan Undang-Undang tentang Wakaf ini ialah salah satu wujud keniscayaan buat membangun hukum nasional yang pula bagaikan perlengkapan ataupun media buat menggapai kesejahteraan universal yang lain.

\footnotetext{
${ }^{15}$ Jaih Mubarok, Wakaf Produktif. (Bandnung; Simbiosa Rekatama, 2008), 57.
} 


\section{Tata cara dan pendaftaran wakaf}

a. Tata cara wakaf

Supaya perwakafan tanah bisa dilaksanakan dengan tertib, hingga tata cara perwakafannya juga wajib dilakukan sesuai dengan syarat yang berlaku baik bagi syar'i ataupun peraturan perwakafan yang menguraikan tata metode ataupun proses perwakafan secara perinci, seperti dibawah ini: ${ }^{16}$

1) Peraturan Pemerintah No 28 Tahun 1977 Pasal 9 Tentang Tata Cara Perwakafan Tanah Milik:

a. Pihak yang hendak hendak mewakafkan tanahnya diwajibkan tiba di hadapan Pejabat Pembuat Akta Ikrar Wakaf buat melakukan Ikrar Wakaf.

b. Pejabat Pembuat Akta Ikrar Wakaf serupa yang diartikan dalam ayat (1) dinaikan serta diberhentikan oleh Menteri Agama.

c. Isi serta wujud Ikrar Wakaf diresmikan oleh Menteri Agama.

d. Penerapan Ikrar, dengan demikian pula pembuatan Akta Ikrar Wakaf diduga sah, bila dihadiri serta disaksikan oleh sekurang- kurangnya 2 orang saksi.

e. Dalam melakukan ikrar semacam yang diartikan dalam ayat (1) pihak yang mewakafkan tanah diwajibkan bawa serta menyerahkan kepada Pejabat tersebut dalam ayat (2) suratsurat berikut:

1. Sertifikat hak milik ataupun ciri fakta pemilikan tanah yang lain.

2. Teks penjelasan dari Kepala Desa yang diperkuat oleh Kepala Kecamatan setempat yang menerangkan kebenaran pemilikan tanah serta tidak tersangkut suatu dalam sengketa.

3. Teks penjelasan registrasi tanah.

4. Izin dari Bupati/ Walikotamadya Kepala Daerah cq. Kepala Sub. Direktorat Agraria setempat.

2) Dalam Undang-Undang No 41 Tahun 2004 pasal 32 hingga pasal 39 dipaparkan kalau: PPAIW atas nama Nazhir mendaftarkan harta barang wakaf kepada lembaga yang berwenang paling lambat 7 hari kerja semenjak akta ikrar wakaf ditandatangani. Dalam registrasi peninggalan wakaf sebagaimana dipaparkan dalam Pasal 32, PPAIW menyatakan: ${ }^{17}$

${ }^{16}$ A. Faishal Haq, Hukum Perwakafan di Indonesia, hlm. 40-41

${ }^{17}$ Ibid., 46. 
a. Salinan akta ikrar wakaf;

b. Surat-surat serta/ ataupun bukti-bukti kepemilikan serta terpaut dokumen yang lain.

PPAIW menyerahkan sertifikat registrasi peninggalan wakaf sebagimana diartikan dalam pasal 34 kepada nadzhir. Dalam perihal penukaran ataupun penunjukan kembali peninggalan wakaf, nazhir melaksanakan regristrasi ulang peninggalan wakaf yang diganti ataupun didistribusikan kembali di Lembaga yang berwenang serta Badan Wakaf Indonesia lewat PPAIW ataupun ganti alokasi sesuai dengan syarat yang berlaku dalam tata cara registrasi peninggalan wakaf.

Menteri serta Badan Wakaf Indonesia bertanggungjawab buat mengelola peninggalan wakaf, Menteri serta Badan Wakaf Indonesia mengumumkan kepada publik peninggalan wakaf yang terdaftar.

Sebaliknya dalam UU No 41 Tahun 2004 pasal 34-39 ditegaskan jika: ${ }^{18}$

1. PPAIW atas nama Nazhir mendaftarkan harta barang wakaf kepada Lembaga yang berwenang sangat lambat 7 hari kerja semenjak akta ikrar wakaf ditandatangani. Pasal 33 menegaskan, dalam registrasi peninggalan wakaf sebagaimana yang diartikan dalam Pasal 32, PPAIW menganjurkan:

a. Salinan akta ikrar wakaf;

b. Surat-surat ataupun bukti-bukti kepemilikan serta dokumen terpaut yang lain.

\section{Kriteria-kriteria keabsahan harta wakaf yang belum bersertifikat}

Perundang-undangan perwakafan yang telah dikeluarkan itu ternyata dalam penerapannya masih belum berjalan sebagaimana yang diharapkan, masih banyak hadapi hambatan. Hambatan- itu antara lain:19

a. Peraturan Pemerintah Nomor 28 tahun 1977 belum memasyarakat di tengah- tengah kehidupan warga ialah umat Islam.

b. Tanah wakaf saat sebelum terbitnya PP Nomor. 28 Tahun 1977 mayoritas belum memiliki informasi yang autentik. Oleh sebab itu, dalam proses menyesuaikan diri dengan PP kerap terjalin

\footnotetext{
${ }^{18}$ Ibid., 46-47.

19 Ainur Rochman, "Tinjauan Hukum Islam dan Undang-Undang RI Nomor 41 Tahun 2004 Tentang Wakaf Terhadap Tanah Wakaf Masjid dan Mushola Yang Tidak Bersertifikat di Desa Cangkring Malang, Kecamatan Bei, Kabupaten Pasuruan”, Skripsi UIN Sunan Ampel Surabaya (2011), 44.
} 
permasalahan antara nazhir dengan keluarga wakif, antara nazhir dengan pemerintah, serta antara nazhir dengan pihak yang tidak bertanggungjawab.

c. Ada banyak tempat ibadah, gedung lembaga keagamaan serta kuburan yang menempati tanah Negera yang belum tertampung dalam PP Nomor 28 buat berganti statusnya jadi tanah wakaf.

d. Terbatasnya dana buat persertifikatan tanah wakaf. Di Indonesia masih banyak sekali masalah-masalah yang menimpa permasalahan wakaf, salah satunya ialah banyaknya tanah-tanah wakaf yang belum bersertifikat. Aspek yang menimbulkan banyaknya tanah wakaf yang tidak bersertifikat, ialah:

1) Minimnya uraian terhadap peraturan- peraturan yang menyangkut prosedur registrasi tanah.

2) Terdapatnya sebagian surat-surat fakta hak tentang tanah yang sudah tidak ada lagi.

3) Sedikitnya tenaga eksklusif buat menekuni registrasi tanah.

4) Masih terdapat yang berpikiran kalau dari warga ini walaupun tanpa sertifikat, peran tanah wakaf ini sangat lumayan kokoh ataupun kepastian hukumnya sangat terjamin.

Faktor- faktor seperti itu yang hendak jadi pemicu banyaknya tanahtanah wakaf di Indonesia yang belum bersertifikat. Sedikitnya pengetahuan warga serta pemahaman warga bakal berartinya sertifikat tanah wakaf pula menunjang perihal tersebut.

Warga di pedesaan tradisional, telah terbiasa serta sangat mengerti dengan tata cara simpel bermacam jalinan di antara mereka, tercantum ikatan hukum (semacam jual beli, sewa menyewa, perjanjian kerja, serta lain lain). Tidak diperlukan banyak prosedur serta fakta tertulis. Dukungan dari kepala desa telah tercantum legalisasi yang kokoh. Oleh sebab itu, lembaga registrasi ataupun pembuatan sertifikat tanah pula baru untuk mereka serta bisa jadi mereka wajib berusuan dengan kepala desa, KUA kecamatan, camat, serta Kantor Agraria. Oleh sebab itu secara sederhananya mereka hendak membuat kalkulasi, berhitung-hitung berapa banyak tenaga, waktu serta pengeluaran yang wajib mereka pakai buat menuntaskan pengurusan registrasi tanah, di pihak lain juga mereka hendak memandang guna apa yang diperoleh dengan registrasi tersebut. Keabsahan wakaf pula didasarkan atas 4 perihal, sebagai berikut: ${ }^{20}$

1. Benda wakaf itu bisa dijual belikan serta membolehkan kemanfaatanya secara jangka panjang tanpa mengalami kehancuran pada bendanya.

${ }^{20}$ Ibid., 46-47. 
2. Wakaf mesti diperuntukan buat kebaikannya (al- birr), semacam buat orang- orang miskin, tempat ibadah serta kepentingan universal.

3. Haqq al-Tamalluk ialah wakaf yang sebaiknya diserahkan kepada orang-orang yang memiliki hak buat mempunyai sesuatu. Dengan demikian wakaf tidak sah diberikan keabsahannya.

4. Wakaf dilakukan secara langsung tanpa digantungkan kepada suatu yang syaratnya semacam persyaratan:... aku hendak mewakafkan... bila aku telah mati.

\section{Metode Penelitian}

Penelitian yang dilakukan oleh peneliti, menggunakan metode Metode yang digunakan dalam riset ini merupakan metode riset yuridis normatif. Riset yuridis normatif yang besifat kualitatif merupakan riset yang mengacu pada norma hukum yang ada dalam peraturan perundangundangan serta vonis norma- norma yang hidup serta tumbuh dalam warga. ${ }^{21}$ Riset ini tercantum kategori riset hukum normatif ataupun riset hukum kepustakaan. Riset hukum dengan kata lain riset normatif ialah riset dengan kepustakaan yang diambil dari buku- buku, literatur ilmu hukum. ${ }^{22}$

\section{Hasil Penelitian}

Status hukum barang wakaf yang belum mempunyai sertfikikat yang dikeluarkan oleh pejabat yang berwenang, hingga yang menghasilkan sertifikat ialah pejabat BPN yang sah. Ketentuan yang bisa memastikan sah ataupun tidaknya suatau wakaf serta bukan ditentukan dari sertifikatnya, melainkan pula sangat ditentukan oleh kemauan seseorang wakif buat mewakafkan tanahnya. Di dalam pasal 2 UndangUndang No 41 Tahun 2004 tentang Wakaf kalau dengan memastikan wakaf secara sah apabila dilaksanakan sesuai dengan syariah.

Kedudukan dari AIW ini sangat berfungsi penting untuk pihak yang hendak ingin melaksanakan wakaf. Dalam pembuatan AIW pula memiliki arti yang sangat berarti, sebab dengan dibuatnya AIW ini, hingga dalam perwakafan ini teruji secara autentik dalam akta yang hendak menemukan, melindungi serta menjamin atas eksistensi pada wakaf tersebut. Sehingga dimana bisa dipergunakan sebaik mungkin dalam berbagai masalah-masalah yang terdapat. Tetapi kenyataannya masih ada pula penerapan wakaf yang bisa jadi dikerjakannya cuma penuhi

${ }^{21}$ Zainuddin Ali, Metode Penelitian Hukum, (Jakarta: Sinar Grafika, 2011), 105.

${ }^{22}$ Soerjono; Abdurrahman, Metode Penelitian Hukum, (Jakarta; Rineka Cipta, 2003), 1. 
ketentuan sahnya dalam wakaf bagi hukum Islam tanpa pembuatan AIW itu.

Dalam konteks hukum syariat, wakaf yang tanpa terdapatnya persertifikatan pula hendak senantiasa sah bila dalam seluruh wujud ketentuan serta rukun yang sudah ditetapkan dalam syariat Islam yang terpenuhi dengan baik. Dengan terdapatnya pencatatan serta persertifikatan wakaf ini hanyalah administrasinya saja, bukan jadi sebagian faktor yang menentukan apakah sah ataupun tidaknya wakaf tersebut. Apalagi para fuqaha tidak mencantumkan para nadzhir wakaf sebagai salah satu rukun dari wakaf, perihal ini diakibatkan sebab mereka berpendapat kalau itu termasuk ibadah tabbaru' ataupun sesuatu pemberian yang bersifat sunnah. Memanglah tidak bisa dipungkiri kalau peran nazhir ini sesuatu perihal yang sangat berarti, sebab nazhir pula sangat bertanggungjawab buat melindungi serta memelihara tanah wakaf hingga memberdayakan tanah yang sudah diwakafkan. ${ }^{23}$

Menurut jumhur ulama, akad wakaf ini bersifat mengikat yang dengan kata lain apabila dengan terpenuhi rukun serta ketentuan dari wakaf ini hingga konsekuensi yang bakal timbul ialah para wakif tidak akan dapat menarik kembali harta yang telah diwakafkan, tidak boleh menjual maupun mewariskan kepada orang lain. Dalam makna, harta benda wakaf yang telah jadi hak universal ini bisa dipergunakan oleh warga penerima wakaf. Ada di pasal 6 UU No 41 Tahun 2004 kalau dalam faktor yang wajib dipenuhi dalam tata pelaksanaan wakaf ialah wakif, nazhir, harta barang wakaf, ikrar wakaf, peruntukan harta barang wakaf serta jangka waktu wakaf. Sebaliknya sertifikat tanah wakaf ini sebagai ketentuan administrasi yang wajib dipenuhi biar dengan terdapatnya sertifikat ini bisa menjadi fakta yang kokoh kalau tanah wakaf ini sudah diwakafkan.

Dengan terdapatnya sertifikat tanah bisa membagikan sebagian guna untuk pewakafnya, antara lain sebagai berikut: pertama, supaya tertib dalam beradministrasi serta pula memberikan data yang lumayan buat menghidari terjalin perkara hukum yang di kemudian hari dari ketidak adanya fakta yang konkrit menunjukkan kalau harta tersebut telah diwakafkan. Kedua, dengan terdapatnya kepuasan dari batin untuk para pewakaf sebab mereka melaksanakan sesuai dengan mekanisme peraturan yang terdapat di perundang-undangan. Ketiga, menjamin bahwasannya kepastian hukum para pihak yang terlibat. Tanah wakaf yang hendak menemukan proteksi hukum ini dari tindakan seorang yang tidak ingin bertanggungjawab.

${ }^{23}$ Zahrul Fatahillah, "Perlindungan Hukum Tanah Wakaf Yang Tidak Memiliki Sertifikat (Studi terhadap Putusan Wakaf di Mahkamah Syar'iyah Aceh)”, Jurnal Kalam, 7, 1 (2019), 75-76 
Menurut Adrian Sutandi, seluruh perbuatan yang dilakukan bisa mempengaruhi kepunyaan yang dicatat dalam satu dokumen, ialah dengan dikerjakannya registrasi tanah yang setelah itu hendak diterbitkan jadi sertfikat tanah, serta sertifikat tanah itu menjadi data kepemilikannya. Dengan terdapatnya syarat ini jadi sesuatu dasar untuk seluruh umat Islam di Indonesia dalam mendaftarkan tanah wakafnya. Sepanjang dalam penerapan wakaf yang dijalankan sesuai dengan apa yang sudah diatur dalam hukum syariah hingga sudah dianggap sah. ${ }^{24}$

Perhatian dari Pemerintah teradap sertifikat tanah wakaf ini sangat besar. Perihal ini pula bisa dilihat dari Keputusan Bersama antara Kementerian Agama dengan Badan Pertanahan Nasional No 422 Tahun 2004, 3/ SKB/ BPN/ 2004. Serta tujuannya ialah buat memacu dari pendataan tanah wakaf yang masih belum mempunyai sertifikat. Dalam perihal memperhitungkan tanah wakaf di Indonesia yang masih belum bersertifikat serta butuh dilakukan pengecekan atas tanah wakaf tersebut bertujuan buat meningkatkan dari persertifikatan guna buat mentertibkan dalam beradministrasi serta atas kepastian dalam haknya. Kepastian hukum ini dimaksudkan ialah dengan metode melihat dari bukti-bukti yang sudah didatangkan oleh para pihak. Dalam konteks tanah wakaf ini, seperti perlengkapan data yang butuh diajukan ialah Akta Ikrar Wakaf (AIW), sertifikat tanah wakaf dimana sesuatu peralihan hak antara pewakaf kepada nazhir, saksi-saksi yang menyaksikannya secara langsung dalam proses berwakaf, serta fakta yang lain yang bisa menunjang.

Sertifikat hak atas indikasi ini seperti tanda fakta yang sudah diterbitkan oleh lembaga hukum yang telah berwenang (Badan ataupun Pejabat Tata Usaha Negara), yang berisi informasi yuridis dan informasi raga yang hendak digunakan bagaikan salah satu perlengkapan fakta kepemilikan hak atas tanah dengan tujuan memberikan jaminan suatu kepastian hukum serta kepastian hak atas sebidang tanah yang sudah dipunyai oleh seorang ataupun dari badan hukum. Dengan adanya sertifikat ini, hingga dengan diharapkan secara yuridis bisa memberikan jaminan kepastian hukum serta hak oleh negara selaku pemegang hak atas tanahnya. Begitu pula kebalikannya, bila tanah wakaf tersebut tidak terdapatnya sertifikat hingga konsekuensinya apabila di kemudian hari ada kemunculan yang tidak terduga ialah persengketaan tanah. Bisa jadi dalam perihal ini terjalin apabila pewakafnya meninggal dunia. Ahli waris ataupun pihak yang merasa berhak hendak menggugat tanah yang sudah diwakafkan ini kepada nazhir untuk kekuasaan hak miliknya. Serta

${ }^{24}$ Ibid., 76. 
apabila ahli waris ataupun pihak yang saat ini ini masih hidup yang ditinggalkan tidak mengenali tentang keberadaan asal usul tanah wakaf tersebut, hingga dia masih terdapat hak terhadap harta yang diwakafkan dan ia hendak menuntutnya kembali tanah wakafnya. ${ }^{25}$

Di dalam hukum Islam, sertifikat tanah ini bukan jadi sesuatu keharusan, namun dengan terdapatnya perkara yang kerap timbul pasca meninggalnya si pewakaf ini hingga sudah saatnya tanah yang diwakafkan yang masih belum bersertifikat ini buat mengurusnya segera kepada BPN di Kabupaten/ Kota masing- masing. Dalam Islam ini bisa jadi tanpa terdapatnya sertifikat tanah wakaf tetap sah serta orang yang melaksanakannya juga memperoleh pahala sebab dia pula sudah melakukan suatu perintah yang telah diajarkan oleh agama. Oleh sebab itu ajaran agama Islam dalam berwakaf ini sah bila telah penuhi seluruh rukun serta ketentuan yang telah ditetapkan oleh syariat Islam.

Bila wakaf yang disertifikatkan ini hendak memunculkan problem hukum di kemudian hari. Dengan tujuan pokok dari hukum Islam ialah untuk mewujudkan kemaslahatan, oleh karena itu dengan pengajuan sertifikat tanah wakaf ini jadi sesuatu perihal yang sangat amat dibutuhkan biar menjauhi dari tindakan-tindakan yang hendak membawa mereka malapetaka untuk seorang yang melaksanakannya.

Salah satu dari tujuan yang sudah diharapkan dalam pembuatan hukum syara' yang sebagaimana ialah memelihara atas harta yang sudah diwakafkan kepada pewakaf. Dengan begitu, harta wakaf yang butuh dilindungi biar tidak terdapatnya oknum-oknum yang mengambil kembali atas harta yang sudah diwakafkan oleh pewakaf. Oleh sebab itu, dengan tidak terdapatnya sertifikat yang memaparkan tentang kepemilikan atas harta yang sudah diwakafkan itu. Perihal ini diakibatkan terdapatnya tanah wakaf yang jadi salah satu fakta seperti nazhir apabila terdapat perkara permasalahan status tanah wakaf tersebut ${ }^{26}$

\section{Kesimpulan}

Bersumber pada riset yang dilakukan ini, bisa ditarik kesimpulan kalau state tanah wakaf yang tidak mempunyai sertifikat tanah bagi hukum Islam senantiasa legal. Sebagaimana yang dibahas dalam kitabkitab fiqh tidak diatur terdapatnya keharusan untuk pewakaf buat mencatatkan tanah wakafnya. Hingga dalam status tanah wakaf yang masih belum mempunyai sertifikat dalam hukum positif tidak mempunyai terdapatnya kekuatan hukum sehingga hendak bisa menimbulkannya problem di setelah itu hari

\footnotetext{
25 Ibid., 77.

${ }^{26}$ Ibid., $79-80$.
} 
Registrasi serta pencatatan tanah wakaf yang dicoba pada masa saat ini cocok dengan syarat syari'ah, ialah dengan terdapatnya pencatatan tanah wakaf yang hendak mewujudkannya lebih banyak maslahah dari pada mafsadah, sebab bertujuan buat dikerjakannya pencatatan tanah wakaf ialah buat kemaslahatan dari seluruh pihak bagaikan perlengkapan pembuktian bila tanah wakaf yang dipersengketakan. Oleh sebab itu, idealnya tiap tanah wakaf wajib mempunyai proteksi serta kepastian dari status hukum serta untuk tanah wakaf yang tidak mempunyai sertifikat tidak mempunyai proteksi serta kepastian hukum.

\section{Daftar Pustaka}

Ali, Achmad. Menguak Teori Hukum (Legal Theory) dan Teori Peradilan (Judicialprudence) Termasuk Interprtasi Undang-Undang (Legisprudence). Jakarta: Penerbit Kencana, 2009.

Ali, Zainuddin. Metode Penelitian Hukum. Jakarta: Sinar Grafika, 2011.

Djunaidi Ahmad, dkk. Menuju Era Wakaf Produktif. Jakarta; Mumtaz Publishing, 2005.

Faishal, A. Hukum Perwakafan di Indonesia. Surabaya: UIN Sunan Ampel Surabaya Press, 2017.

Fatahillah, Zahrul. "Perlindungan Hukum Tanah Wakaf Yang Tidak Memiliki Sertifikat (Studi terhadap Putusan Wakaf di Mahkamah Syar'iyah Aceh)", Jurnal Kalam, 7, 1, (2019).

Fikri, Dimas Fahmi dkk., "Reformasi Hukum Wakaf di Indonesia Studi terhadap Wakaf Atas Kekayaan Intelektual", Jurnal Al Ahkam, 22, 1, 2012.

Hidayatulloh, Tri Bakti In. “Efektivitas Undang-Undang Nomor 41 Tahun 2004 Pasal 68 Tentang Adminstratif Keterlambatan Pendaftaran Tanah Wakaf Oleh Pejabat Pembuat Akta Ikrar Wakaf (Studi di Kecamatan Sukodadi Kabupaten Lamongan)", Skripsi UIN Maulana Malik Ibrahim Malang (2017).

Mubarok, Jaih. Wakaf Produktif. Bandung; Simbiosa Rekatama, 2008.

Nurhayati, Sri. Akuntansi dan Manajemen Wakaf. Jakarta: Penerbit Salemba Empat, 2019.

Puspadewi, Itaq. "Pengaruh Komunikasi Terhadap Efektifitas Kerja Pada Badan Perencanaan Pembangunan Daerah Kabupaten Kutai Barat", Jurnal Ilmu-Ilmu Sosial, 3, 1, 2014.

Rochman, Ainur. “Tinjauan Hukum Islam dan Undang-Undang RI Nomor 41 Tahun 2004 Tentang Wakaf Terhadap Tanah Wakaf Masjid dan Mushola Yang Tidak Bersertifikat di Desa Cangkring 
Malang, Kecamatan Bei, Kabupaten Pasuruan", Skripsi UIN Sunan Ampel Surabaya (2011).

Soekanto, Soerjono. Faktor-Faktor yang Mempengaruhi Penagakan Hukum. Jakarta: Raja Grafindo Persada, 2007.

Soerjono dkk., Metode Penelitian Hukum. Jakarta; Rineka Cipta, 2003. 